\title{
COMPUTATIONAL ANALYSIS OF THE ENERGY EFFICIENCY OF STONE WALLS: CURRENT SITUATION AND POSSIBLE IMPROVEMENTS
}

\author{
JIŘÍ MADĚRA, VÁCLAV KOČÍ \& ROBERT ČERNÝ \\ Department of Materials Engineering and Chemistry, Faculty of Civil Engineering, Czech Technical \\ University in Prague, Thákurova 7/2077, 16629 Prague 6, Czech Republic.
}

\begin{abstract}
Energy efficiency of selected envelopes of historical buildings is assessed. The historical masonry is represented by two types of sandstone walls with different thicknesses, which are retrofitted using internal thermal insulation systems preserving the original look of the external facades. All energy-related calculations are based on the results of hygrothermal analysis of the studied envelopes exposed to dynamic climatic conditions. The comparison of energy balances of non-insulated and retrofitted walls shows that the reduction of energy loss can reach up to $89 \%$, depending on the type of the wall that is analysed. Hydrophobic and hydrophilic mineral wools exhibit the best results not only from the point of view of energy efficiency but also from that of hygric performance.

Keywords: dynamic simulation, energy balance, interior thermal insulation, mineral wool, retrofitting, sandstone.
\end{abstract}

\section{INTRODUCTION}

Thermal insulating properties of building materials play a very important and, sometimes, even a decisive role in the field of energy consumption. As the energy consumed by heating accounts for the largest part of the overall energy consumption of buildings [1], the current trends in the building industry aim at improving the qualities of building envelopes from the point of view of their thermal properties. This means that either new types of building materials with excellent thermal insulating skills are developed [2-3] or that thermal insulations become integral part of envelopes. Most of the older buildings are retrofitted as well [4-5].

On the other hand, common reconstruction treatments of old buildings are not always possible since some of them may be under the protection of preservationists who insist on maintaining the original facades of the buildings. Especially in metropolises, the share of buildings under the surveillance of preservationists may be appreciable. These buildings are usually represented not only by the old town sights such as churches, cathedrals or other sacral buildings but also by schools and older residential or commercial buildings in the city centres.

Most of the historical buildings are made of materials typical for the period they have been built in. One can find objects built of wood or solid clay bricks, but the largest part is made of natural stones that proved to have excellent physical properties as well as durability. In addition, magnificence and aesthetic function are also characteristic of natural stones. However, their weakest point can be seen in their poor thermal insulating capabilities [6]. This disadvantage used to be overcome by the extensive thickness of the walls, but according to current thermal standards this is not enough anymore. Therefore, solutions to meet the conditions of both preservationists and thermal standards are being sought. 


\section{COMPUTATIONAL ANALYSIS}

The computational analysis was performed after several input parameters had been gathered. It was necessary to select proper mathematical models, draw an analysed construction detail including its mesh, assign boundary conditions and material parameters, choose time interval and specify time step of simulation. The detailed description is provided in the following section. Based on the input data, the hygrothermal performance of the selected construction detail was investigated using the computer code HEMOT [7], which was developed at the Department of Materials Engineering and Chemistry, Faculty of Civil Engineering, Czech Technical University in Prague. It works on the basis of the general finite element package SIFEL [8].

\subsection{Analysed construction detail}

As a representative wall of historical buildings, solid stone walls having two different thicknesses were selected: $500 \mathrm{~mm}$ and $800 \mathrm{~mm}$. At first, these walls were analysed as stand-alone, i.e. without thermal insulation materials and with only plasters from both sides. In the second phase, several types of thermally insulating layers were applied on the interior side as the preservation authorities usually insist in maintaining the original look of historical facades. The scheme of analysed stone masonry is provided in Fig. 1.

\subsection{Material parameters}

Two types of sandstone were analysed in this article. The first one originates in the Úpice quarry, the second one comes from the Záměl quarry. As thermal insulations, expanded polystyrene (EPS), hydrophobic (MW1) and hydrophilic mineral wool (MW2) were used. The lime-cement based plaster was assumed from both sides of the wall.

All the basic physical, heat and moisture transport and storage parameters used as input data (see Tables 1 and 2) were measured in the laboratories of the Department of Materials
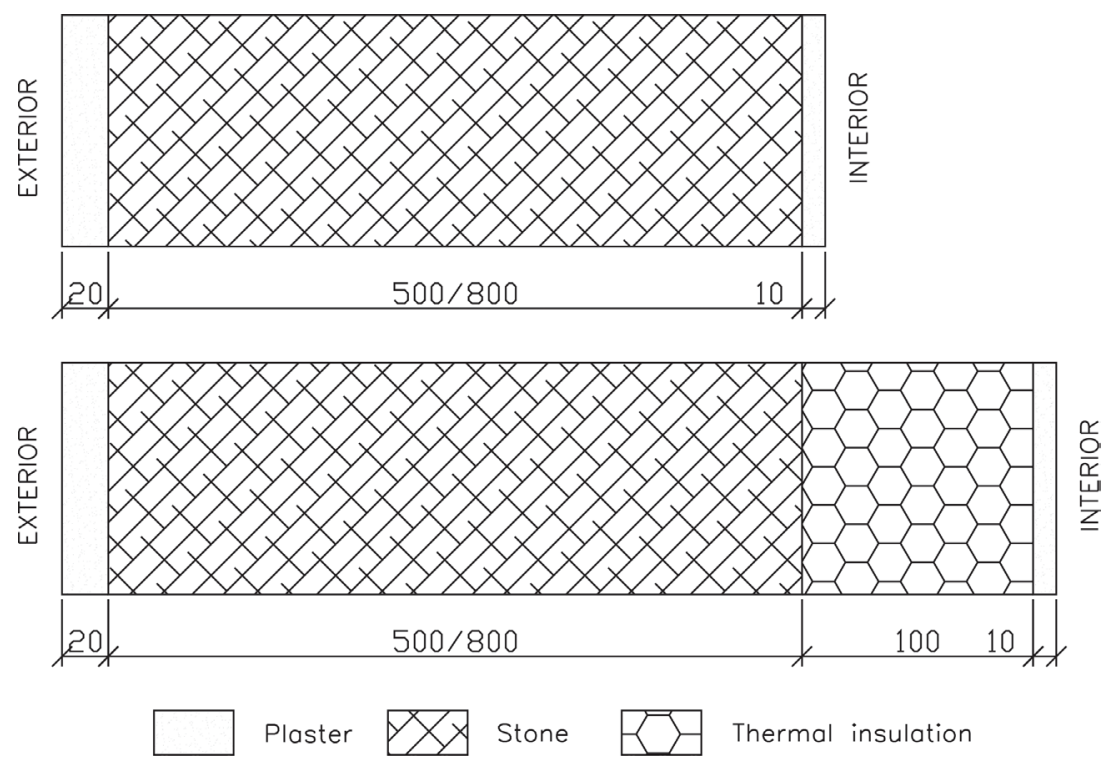

Figure 1: Scheme of analysed construction detail. 
Table 1: Material characteristics of stone and plaster.

\begin{tabular}{lccc}
\hline Parameter & Sandstone Úpice & Sandstone Záměl & Lime-cement plaster \\
\hline$\rho\left[\mathrm{kg} \mathrm{m}^{-3}\right]$ & 2,433 & 2,076 & 1,244 \\
$\psi[\%]$ & 7.3 & 22.8 & 49.8 \\
$c\left[\mathrm{~J} \mathrm{~kg}^{-1} \mathrm{~K}^{-1}\right]$ & $646-734$ & $694-1,098$ & $1,054-1,592$ \\
$\mu[-]$ & 76.9 & $6.9-11.8$ & $5.5-7.5$ \\
$\lambda_{d r y}\left[\mathrm{~W} \mathrm{~m}^{-1} \mathrm{~K}^{-1}\right]$ & 3.665 & 2.10 & 0.296 \\
$\lambda_{\text {sat }}\left[\mathrm{W} \mathrm{m}^{-1} \mathrm{~K}^{-1}\right]$ & 4.167 & 3.88 & 0.943 \\
$\kappa_{\text {app }}\left[\mathrm{m}^{2} \mathrm{~s}^{-1}\right]$ & $1.12 \mathrm{e}-7$ & $7.76 \mathrm{e}-7$ & $8.30 \mathrm{e}-9$ \\
$w_{\text {hyg }}\left[\mathrm{m}^{3} \mathrm{~m}^{-3}\right]$ & 0.0083 & 0.0038 & 0.0144 \\
\hline
\end{tabular}

Table 2: Material characteristics of thermal insulations.

\begin{tabular}{lccc}
\hline Parameter & EPS & MW1 & MW2 \\
\hline$\rho\left[\mathrm{kg} \mathrm{m}^{-3}\right]$ & 16.5 & 100 & 70 \\
$\psi[\%]$ & 98.4 & 96.6 & 96.9 \\
$c\left[\mathrm{~J} \mathrm{~kg}^{-1} \mathrm{~K}^{-1}\right]$ & 1,570 & 790 & 810 \\
$\mu[-]$ & $29.0-58.0$ & $1.3-2.6$ & $1.2-2.4$ \\
$\lambda_{d r y}\left[\mathrm{~W} \mathrm{~m}^{-1} \mathrm{~K}^{-1}\right]$ & 0.037 & 0.036 & 0.037 \\
$\lambda_{\text {sat }}\left[\mathrm{W} \mathrm{m}^{-1} \mathrm{~K}^{-1}\right]$ & 0.513 & 0.701 & 0.790 \\
$\kappa_{\text {app }}\left[\mathrm{m}^{2} \mathrm{~s}^{-1}\right]$ & $1.50 \mathrm{e}-9$ & $6.10 \mathrm{e}-11$ & $8.50 \mathrm{e}-6$ \\
$w_{\text {hyg }}\left[\mathrm{m}^{3} \mathrm{~m}^{-3}\right]$ & 0.00018 & 0.00021 & 0.00026 \\
\hline
\end{tabular}

Engineering and Chemistry, Faculty of Civil Engineering, Czech Technical University in Prague [6, 9-11] according to the methodology presented in [12].

The used symbols have the following meaning: $\rho$ - bulk density $\left[\mathrm{kg} \mathrm{m}^{-3}\right], \psi$ - porosity [\%], $c$ - specific heat capacity [ $\left.\mathrm{J} \mathrm{kg}^{-1} \mathrm{~K}^{-1}\right], \mu$ - water vapor diffusion resistance factor [-], $\lambda$ - thermal conductivity [W $\left.\mathrm{m}^{-1} \mathrm{~K}^{-1}\right], \kappa_{a p p}$ - apparent moisture diffusivity $\left[\mathrm{m}^{2} \mathrm{~s}^{-1}\right.$, $w_{\text {hyg }}$ - hygroscopic moisture content by volume $\left[\mathrm{m}^{3} \mathrm{~m}^{-3}\right]$.

\subsection{Mathematical model}

The transport of heat and moisture was described by balance equations formulated in Künzel's mathematical model [13]. It is one of the most frequently used mathematical models because of its several advantages such as use of relative humidity $\varphi$ for description of coupled water and water vapor transport, which allows moisture content to be expressed by a continuous quantity on a material interface. Although it contains several simplifications, the main phenomena are retained. Therefore, it requires only a tight set of input parameters that make it predestined for wide applications in the field of building physics. This model was verified and successfully applied in numerous hygrothermal simulations earlier. 


\subsection{Boundary conditions and time interval of simulation}

Dynamic climatic conditions in the form of test reference year (TRY) for Olomouc were applied on the exterior side of analysed building envelopes in order to obtain as realistic results as possible. Olomouc is the historical metropolis of the Moravian region of the Czech Republic with a large number of sacral buildings. TRY contains long-term average hourly values of several weather parameters such as temperature, relative humidity, wind velocity, wind direction, rainfall or sun radiation. These data were obtained from the Czech Hydrometeorological Institute. The boundary conditions on the interior side of building envelopes were assumed as constant and were set to $21^{\circ} \mathrm{C}$ and $55 \%$ of relative humidity.

The results of the hygrothermal simulations have to be evaluated after a certain period of time which is necessary for the properties to achieve a kind of dynamic equilibrium, as the hygric and thermal properties of building materials used as input parameters depend on the state variables such as temperature or moisture content. Therefore, the results of the hygrothermal performance presented in this article are related to the tenth year of simulation which is, according to the previous experience, long enough for the development of cyclic hygrothermal behaviour.

\subsection{Energy balance estimation}

The energy efficiency calculated in this article expresses the annual amount of heat transported through the envelope. It is calculated as the time integral of heat flux according to the relation

$$
Q=\int_{1 J a n}^{31} q(t) d t
$$

where $Q$ denotes the energy transferred through a square meter of the envelope per annum $\left[\mathrm{kWh} \mathrm{m}_{\text {env }}^{-2} \mathrm{a}^{-1}\right]$ and $q(t)$ is the heat flux as a function of time $\left[\mathrm{W} \mathrm{m}^{-2}\right.$ env $]$ in a boundary element of the building envelope cross-section. It is calculated as

$$
q=-\lambda(w) \frac{d T}{d x}
$$

where $\lambda(w)$ is the thermal conductivity depending on the moisture content $\left[\mathrm{W} \mathrm{m}^{-1} \mathrm{~K}^{-1}\right], d T$ is the difference between temperatures of two nodes defining the boundary element $[\mathrm{K}]$ and $d x$ is the size of the element [m].

In order to quantify the contribution of retrofitting the envelope to the energy efficiency, reference envelope without thermal insulation was also analysed.

\section{RESULTS AND DISCUSSION}

The annual energy balances of one square meter of reference building envelopes, i.e. made of stones without thermal insulation, proved to be very inefficient, no matter how thick they were. The difference between particular stones was only marginal and better results were achieved when Záměl sandstone was assumed. This is in accordance with the values of thermal conductivity presented in Table 2 . By increasing the thickness of the wall by $300 \mathrm{~mm}$, the annual amount of energy transported through one square meter of the envelope was reduced approximately by $16 \%-20 \%$. It is therefore obvious that increasing the thickness is not an 


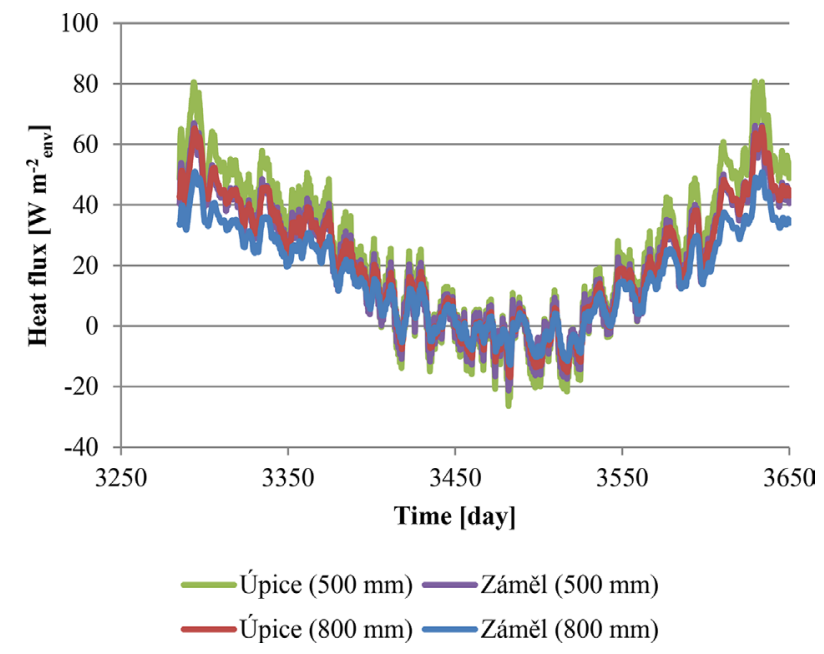

Figure 2: Time function of heat flux - external walls without thermal insulation.

Table 3: Annual energy balance - external walls without thermal insulation.

\begin{tabular}{lcccccr}
\hline & \multicolumn{2}{c}{ Sandstone Úpice } & & \multicolumn{2}{c}{ Sandstone Záměl } \\
\cline { 2 - 3 } & $500 \mathrm{~mm}$ & $800 \mathrm{~mm}$ & & $500 \mathrm{~mm}$ & $800 \mathrm{~mm}$ \\
\hline Energy balance $\left[\mathrm{kWh} \mathrm{m}_{\text {env }}^{-2} \mathrm{a}^{-1}\right]$ & 219.99 & 181.58 & & 180.32 & 142.52 \\
\hline
\end{tabular}

effective approach from the point of view of energy balance. The time functions of heat fluxes through particular envelopes are provided in Fig. 2, and the summary of energy balances is provided in Table 3.

By providing the walls with interior thermal insulation systems, the annual energy balances were substantially improved as all the considered insulation materials have excellent thermal properties (see Table 2). As one can see in Figs 3 and 4, the differences between particular material solutions are very small and barely distinguishable. It can be explained by the similar thermal properties of applied thermal insulations and, in particular, by the application of the insulation on the interior side. This means that the hygric behaviour of the wall cannot be controlled by the thermal insulation which thus cannot protect it against excessive moisture intake due to exposure to weather conditions. Because thermal parameters of building materials are strongly dependent on the moisture content that is very similar in all the investigated variations, the thermal behaviour is therefore also almost identical.

The summary of energy balances of particular building envelopes is provided in Tables 4 and 5 .

Despite the fact that the extent of the improvement was higher by $\sim 2 \%-3 \%$ in the case of thinner walls, the absolute annual energy balance of thicker walls remained better by 0.60 $1.98 \mathrm{kWh} / \mathrm{m}^{2}$ env a. However, the absolute numbers are very small compared to the original values $\left(142.54-219.99 \mathrm{kWh} / \mathrm{m}^{2}\right.$ env a), so one can conclude that all the insulating materials 


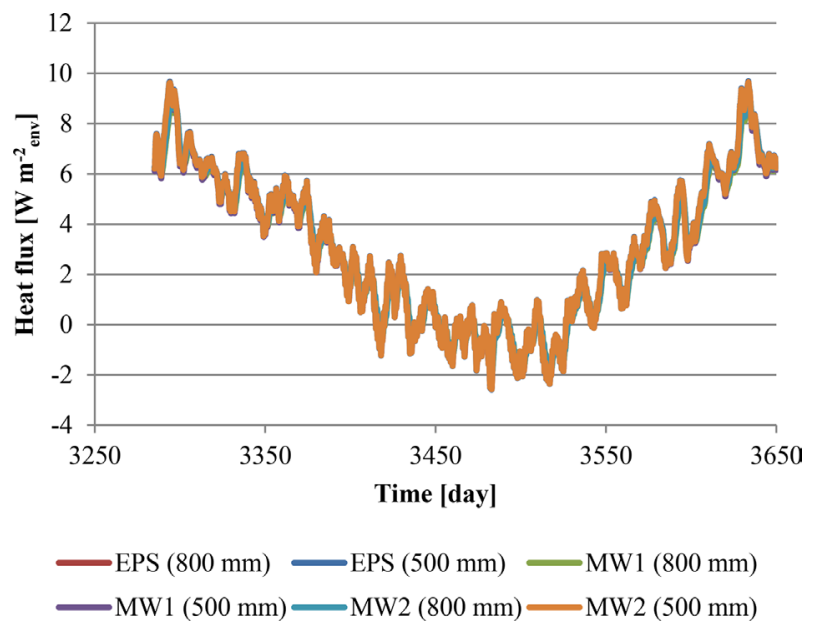

Figure 3: Time function of heat flux - Záměl sandstone.

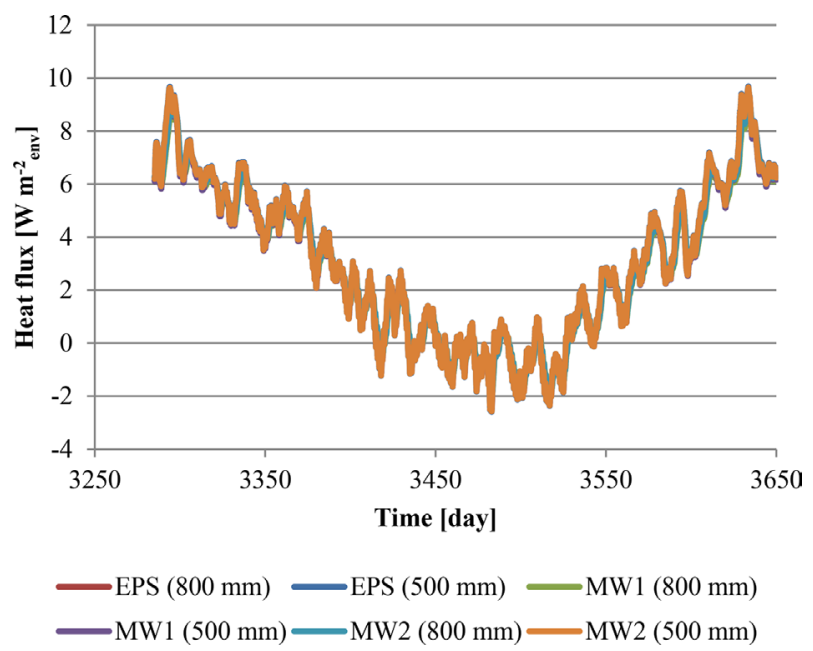

Figure 4: Time function of heat flux - Záměl sandstone.

Table 4: Annual energy balance $-800 \mathrm{~mm}$.

\begin{tabular}{lcclcc}
\hline & \multicolumn{2}{c}{ Sandstone Úpice } & & \multicolumn{2}{c}{ Sandstone Záměl } \\
\cline { 2 - 3 } \cline { 5 - 6 } & $Q\left[\mathrm{kWh} / \mathrm{m}_{\text {env }}^{2} \mathrm{a}\right]$ & Improvement $[\%]$ & & $Q\left[\mathrm{kWh} / \mathrm{m}_{\text {env }}^{2} \mathrm{a}\right]$ & Improvement [\%] \\
\hline Un-insulated & 181.58 & - & & 142.54 & - \\
EPS & 26.24 & 85.55 & & 25.27 & 82.27 \\
MW1 & 25.61 & 85.90 & & 24.68 & 82.69 \\
MW2 & 26.14 & 85.60 & & 25.17 & 83.04 \\
\hline
\end{tabular}


applied from the interior side that were investigated showed excellent thermal performance and the best results were obtained after hydrophobic mineral wool had been applied on the 800 -mm thick wall made of sandstone from the Záměl quarry $\left(Q=24.68 \mathrm{kWh} / \mathrm{m}^{2}{ }_{\text {env }}\right.$ a).

Unlike thermal performance, the hygric performance of particular envelopes is not so similar. Because thermal insulation slows down the transport of water vapour through the wall, it contributes to higher accumulation of moisture inside the masonry. The rate of accumulation depends on the water vapour transport properties and generally it is observed that the lower the water vapour resistance factor, the lower the moisture content. Hence, higher moisture content can be observed when EPS is applied. Moisture diffusivity of thermal insulation is another factor affecting the hygric performance of the envelope, as it may help to hasten moisture redistribution and thus prevent its accumulation. The time function of moisture content on the interface between Úpice sandstone $(800 \mathrm{~mm})$ and thermal insulation is depicted in Fig. 5. It is obvious that EPS can increase the relative humidity up by $7.2 \%$ compared to an un-insulated wall, while MW1 and MW2 can increase the same only by $1.1 \%$. A comparison of moisture profiles on a summer day of reference year (July 10) is provided in Fig. 6 highlighting the differences in hygric performance.

The presented results only proved the fact that capillary active materials are most suitable as interior thermal insulations [13] as they can prevent excessive moisture accumulation that occurs due to the inverse sequence of layers in the composition of an external wall while the thermal performance is substantially increased.

Table 5: Annual energy balance $-500 \mathrm{~mm}$.

\begin{tabular}{lcclcc}
\hline & \multicolumn{2}{c}{ Sandstone Úpice } & & \multicolumn{2}{c}{ Sandstone Záměl } \\
\cline { 2 - 3 } \cline { 5 - 6 } & $Q\left[\mathrm{kWh} / \mathrm{m}_{\text {env }}^{2} \mathrm{a}\right]$ & Improvement $[\%]$ & & $Q\left[\mathrm{kWh} / \mathrm{m}_{\text {env }}^{2} \mathrm{a}\right]$ & Improvement [\%] \\
\hline Un-insulated & 219.99 & - & & 180.32 & - \\
EPS & 26.88 & 87.78 & & 26.25 & 85.44 \\
MW1 & 26.21 & 88.09 & & 25.61 & 85.80 \\
MW2 & 26.78 & 87.83 & & 26.15 & 85.50 \\
\hline
\end{tabular}

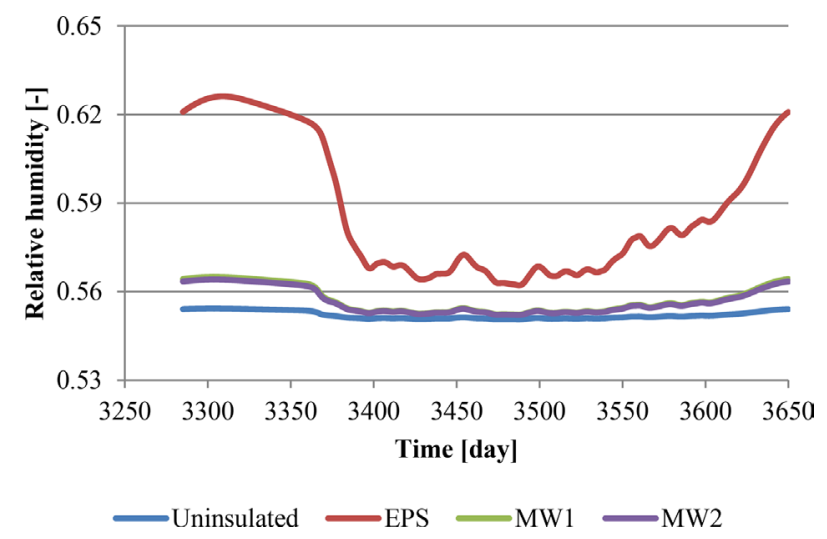

Figure 5: Time function of moisture content on the interface between stone and insulation, sandstone Úpice, $800 \mathrm{~mm}$. 


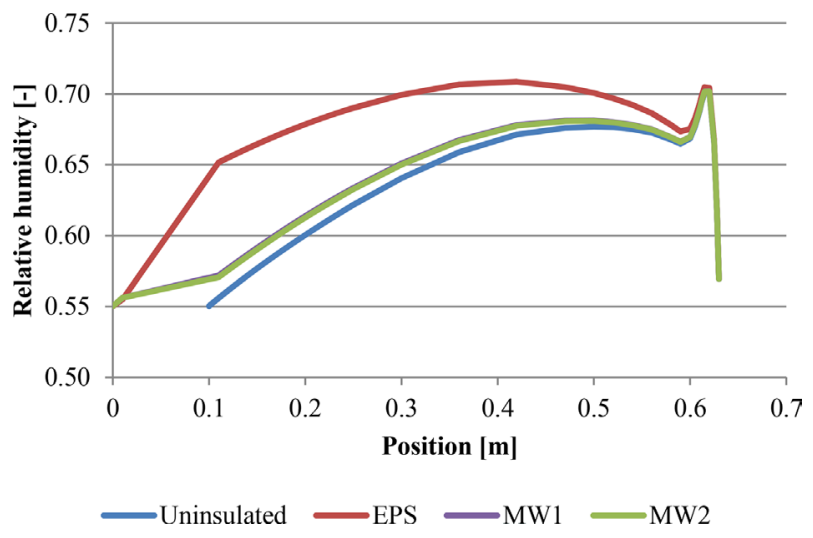

Figure 6: Moisture profiles, sandstone Záměl, 500 mm, July 10.

\section{CONCLUSIONS}

The application of interior thermal insulation systems is a very specific task that is not usually solved as the exterior systems are applied much more frequently. However, in several cases, e.g. as in historical buildings, the interior insulations represent the only way of thermal protection. Then, computational analysis may be a very effective tool for the assessment of hygrothermal performance of walls provided with various types of thermal insulating systems.

In this article, two types of sandstones with different thicknesses were analysed as the representatives of historical masonry. Their energy balance was calculated without thermal insulation and then compared to the results obtained with three different insulation materials applied on the interior side.

The results showed that presence of thermal insulation is absolutely necessary from the point of view of energy balance. The original values of energy balance of non-insulated sandstone walls were reduced from $\sim 142-220 \mathrm{kWh} / \mathrm{m}^{2}$ env a to $\sim 25-27 \mathrm{kWh} / \mathrm{m}^{2}$ env a which represents an improvement of $\sim 82 \%-88 \%$. Because all the insulation materials reached almost similar reduction of energy transported through the envelope, their selection based on such a point of view cannot be decisive enough. Therefore, one should also consider the other aspects such as hygric performance of the walls. It was observed that EPS is not as suitable as mineral wools because its application on the interior side causes increase in moisture content which goes along with some negatives such as increased risk of biodegradation, salt attack or deterioration of physical and thermal properties.

Generally, it can be stated that capillary active materials represent the best choice for interior thermal insulations because they are capable of redistributing the moisture content inside the wall and thus prevent its excessive accumulation.

\section{ACKNOWLEDGEMENT}

This research has been supported by the Czech Science Foundation, under project Nr. 14-17207S "Transport parameters and durability of porous rocks".

\section{REFERENCES}

[1] Chwieduk, D., Towards sustainable-energy buildings. Applied Energy, 76, pp. 211-217, 2003.

http://dx.doi.org/10.1016/S0306-2619(03)00059-X 
[2] Huiskes, D.M.A., Keulen, A., Yu, Q.L. \& Brouwers, H.J.H., Design and performance evaluation of ultra-lightweight geopolymer concrete. Materials \& Design, 89, pp. 516-526, 2016.

http://dx.doi.org/10.1016/j.matdes.2015.09.167

[3] Santos, P., Martins, C. \& Julio, E., Enhancement of the thermal performance of perforated clay brick walls through the addition of industrial nano-crystalline aluminium sludge. Construction and Building Materials, 101, pp. 227-238, 2015. http://dx.doi.org/10.1016/j.conbuildmat.2015.10.058

[4] Kloseiko, P., Arumagi, E. \& Kalamees, T., Hygrothermal performance of internally insulated brick wall in cold climate: a case study in a historical school building. Journal of Building Physics, 38, pp. 444-464, 2015. http://dx.doi.org/10.1177/1744259114532609

[5] Vereecken, E. \& Roels, S., Capillary active interior insulation: do the advantages really offset potential disadvantages? Materials and Structures, 48, pp. 3009-3021, 2015. http://dx.doi.org/10.1617/s11527-014-0373-9

[6] Kočí, V., Maděra, J., Fořt, J., Žumár, J., Pavlíková, M., Pavlík, Z. \& Černý, R., Service life assessment of historical building envelopes constructed using different type of sandstones: a computational analysis based on experimental input data. The Scientific World Journal, 2014(1), pp. 1-12, 2014. http://dx.doi.org/10.1155/2014/802509

[7] Černý, R. (ed), Complex System of Methods for Directed Design and Assessment of Functional Properties of Building Materials: Assessment and Synthesis of Analytical Data and Construction of the System, CTU Prague: Prague, 2010.

[8] Kruis, J., Koudelka, T. \& Krejčí, T., Efficient computer implementation of coupled hydro-thermo-mechanical analysis. Mathematics and Computers in Simulation, 80, pp. 1578-1588, 2010. http://dx.doi.org/10.1016/j.matcom.2008.11.010

[9] Fiala, L., Maděra, J., Vejmelková, E. \& Černý, R., A material database for the computational assessment of the degradation of historical masonry. In Structural Studies, Repairs and Maintenance of Heritage Architecture XIV, Southampton: WIT Press, pp. 347-356, 2015.

http://dx.doi.org/10.2495/STR150291

[10] Jerman, M. \& Černý, R., Effect of moisture content on heat and moisture transport and storage properties of thermal insulation materials. Energy and Buildings, 53, pp. 39-46, 2012. http://dx.doi.org/10.1016/j.enbuild.2012.07.002

[11] Čáchová, M., Koňáková, D., Vejmelková, E., Keppert, M., Polozhiy, K. \& Černý, R., Heat and water vapor transport properties of selected commercially produced plasters. Advanced Material Research, 982, pp. 90-93, 2014, ed. R. Černý, Complex System of Methods for Directed Design and Assessment of Functional Properties of Building Materials and Its Application, CTU Prague: Prague, 2013.

[12] Künzel, H.M., Simultaneous Heat and Moisture Transport in Building Components, Ph.D. Thesis, IRB Verlag: Stuttgart, 1995.

[13] Kočí, V., Maděra, J. \& Černý, R., Computational assessment of energy efficiency and hygrothermal performance of retrofitted historical building envelopes. In Energy and Sustainability VI, Southampton: WIT Press, pp. 185-196, 2015. http://dx.doi.org/10.2495/ESUS150161 